\title{
The Effects of Critical Multiliteracy Learning Models on Mastery of Explanatory Text Concepts
}

\author{
Dadan Setiawan ${ }^{1}$, Tatat Hartati $^{2,}$ Rahman $^{3}$, Isah Cahyani ${ }^{4}$ \\ ${ }^{1}$ Postgraduate of Indonesia University of Education \\ ${ }^{2}$ Indonesia University of Education \\ ${ }^{3}$ Indonesia University of Education \\ ${ }^{4}$ Indonesia University of Education \\ dsetiawan03@upi.edu
}

\begin{abstract}
The aims of this study was to determine the ability to master the concept of elementary school students through the implementation of critical multiliteracy learning models. This research was conducted on fifth grade students of elementary school. The research method used in this study was a quasi-experimental method. The participants in this study amounted to 39 students. Data was collected using tests and rubric. Analysis of data in this research using the t test with SPSS version 20.0 program for windows. Based on the results of the study, it was found that the mastery ability of the explanatory text concept of students experienced a significant increase and was included in the sufficient category. This can be seen from the pretest score obtained by students at 34.74 and the posttest results at 64.23 . Based on the results of the $t$ test the significance value is $0.00<0.05$ thus it can be concluded that there are significant differences between the mastery of students' concepts before and after being given treatment using critical multiliteracy learning models.
\end{abstract}

Keywords: Critical Multiliteracy Model, Mastery of Concepts, Explanatory Text

\section{Introduction}

Teaching language in elementary school have various types of texts that must be mastered by students. One type of text taught to elementary school students is explanatory text [1]. Genres of text responses, generally consisting of two types, namely transactional and expository texts. Based on the two types of texts this response, explanatory texts are included in the type of expository text [2]. Explanatory text is a text that explains the process of the occurrence of something and why something happened $[3,4,5,6,7]$. Explanatory text has a function to explain the process of the occurrence of a phenomenon that occurs and as a means to understand the world and how it works [8,7,9]. Explanatory texts are closely related to various scientific disciplines because the content of the content described in explanatory texts is other fields of study such as the field of science and social studies [10].

Explanatory text topic is important to be mastered by students to make it easier for students to continue their education to the next level. To make it easier for students to master the concept of explanatory text can be done in several ways including the implementation of innovative learning models that can encourage students to have a deeper understanding of the material being studied. One innovative learning model that 
can be applied in learning is a critical multiliteracy learning model. The critical multiliteracy learning model is not only oriented towards mastering 21 st century skills, but also encourages students to obtain critical thinking skills. With critical thinking skills possessed by students can help students to understand the concept of explanatory text well.

The critical multiliteracy learning model is a learning model resulting from the development of the concept of critical literacy [11]. The concept of critical literacy is the ability to criticize text from different perspectives [12]. The multiliteracy concept encourages teachers to act as designers and facilitators in the occurrence of quality, meaningful and enjoyable teaching and learning processes because in the process the teacher accommodates the diversity that students have $[13,14]$. The role of the teacher as a facilitator in multiliteracy learning is in line with Navehebrahim's view that in this modern era the teacher must act as a facilitator in learning [15].

The multiliteracy model is oriented towards achieving 21 st century competence [16]. In addition, the application of the concept of multiliteracy in learning can also develop students' skills in pouring ideas into various contexts [17]. In practice, this critical multiliteracy learning model combines multimodal concepts, so that the learning process becomes more meaningful [18]. Many studies on the application of critical multiliteracy learning models that have been carried out and in the results proved that besides being able to improve students 'writing skills, they can also improve students' understanding in learning and be able to increase student learning motivation $[19,20,21,22,23]$.

The critical multiliteracy learning model has eight learning steps. The syntax of the model was stated by Abidin [11], namely as follows.

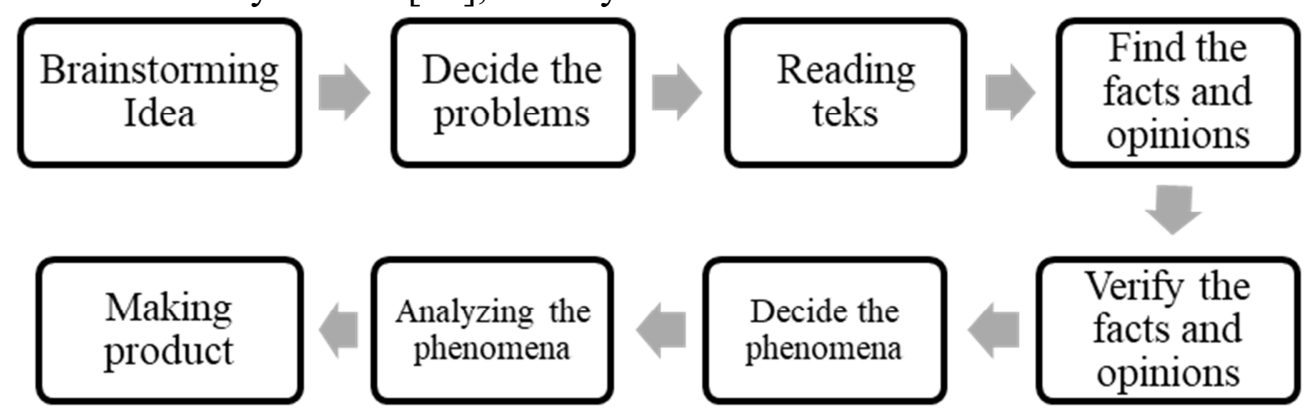

In connection with the steps above, in more detail the steps of the critical multiliteracy learning model will be described in more detail as follows.

a. Brainstorming ideas

In this activity, students devote their ideas or ideas related to a phenomenon that occurs. The phenomenon presented can be natural, social or cultural phenomena.

b. Decide the problems

At this stage, students determine what phenomena they will learn. The phenomenon that students will learn can also be determined by the teacher so that information sources are easily obtained.

c. Reading text

The activity of reading text, students explore information from various sources related to the phenomenon they are studying. At this reading stage, students are expected to be able to collect valid data. 
d. Find the facts and opinions

In the activity of finding facts and opinions, students record which are included in facts and opinions based on the text they read. If students still don't understand facts and opinions, the teacher can explain the material about facts and opinions.

e. Verify the facts and opinions

After students find facts and opinions, students review the facts and opinions that have been written. This is done to ensure that the information can be true, accurate and complete information.

f. Decide the phenomena

At this stage, students determine the phenomenon that students think is interesting to do an investigation. The phenomenon that students analyze is a phenomenon that students will write in explanatory text.

g. Analyzing phenomena

At this stage, students analyze a predetermined phenomenon. At this stage of analysis, students are allowed to read information from various sources. Information obtained by students then students record and are written in the form of story maps.

h. Making product

At this stage, students making product on phenomena that have been analyzed. The works that can be made by students such as written works in the form of famplets, big books, mini books, etc.

\section{Methods}

The aims of this study was to determine the ability to write explanatory texts and mastery of the concepts of elementary school students through the implementation of the RADEC learning model. The method used in this study was a quasi-experimental method with the design of the matching pretest posttest control group design. The number of participants in this study were 38 students. Characteristics of students who are participants in this study are cognitively heterogeneous, meaning that there are students who are cognitively at high, middle and also there are students who are cognitively at a low level. The instrument used in this study is a test and rubric assessment. This test instrument is used to measure the mastery of students' concepts of explanatory texts. The assessment indicators that become a measure of mastery of students' concepts consist of several categories, namely: knowing (C1), understanding (C2), application (C3), analyzing (C4), and evaluating (C5).

The procedure of this study was first carried out pre-test to determine the students' initial abilities. The treatment was then carried out by applying a critical multiliteracy learning model for six meetings. Then the post-test is performed to determine the ability of students after being given treatment. After the data is obtained, the data are analyzed through normality test, homogeneity test, and t test to determine the difference in students' abilities before and after being given learning using critical multiliteracy models. Data processing in this study was assisted by the SPSS version 20.0 for Windows. 


\section{Results and Discussion}

This section is an explanation of the results and the discussion of mastery of explanatory text concepts of students before and after learning is given using the critical multiliteracy model as follows.

\subsection{Result}

Based on the results of the study, it is known that mastery of the explanatory text concept of students is included in the low category. This can be seen from the acquisition of the pretest score that is equal to 34.74. The acquisition of students' pretest scores seen from each aspect can be seen in the following figure.

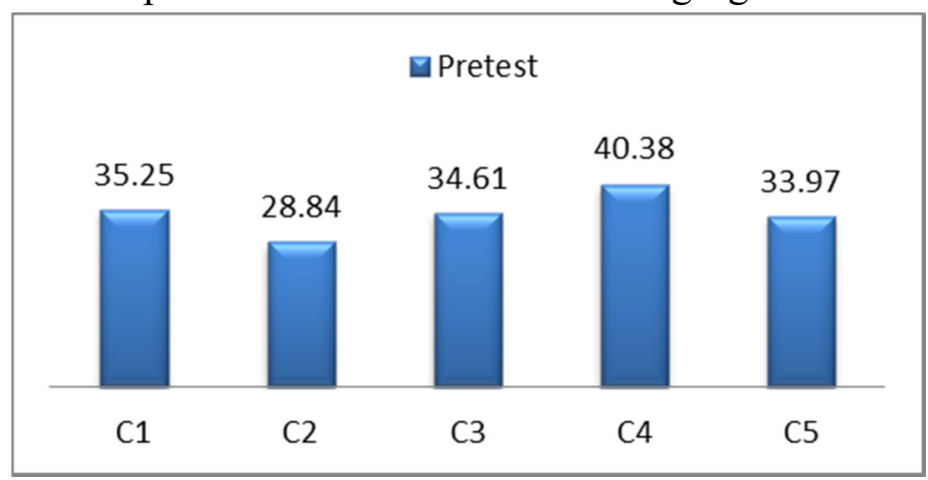

Figure 1. Pretest Results of The Mastery of Concepts

Based on Figure 3.1, it has been shown that the initial ability of mastering students' concepts on the analyzing indicator (C4) is higher compared to other concept mastery indicators. the initial ability of mastering students' concepts on indicators knowing, applying, and evaluating is not significantly different. Indicators of understanding the mastery data of students' initial concepts are lower compared to other concept mastery indicators. This shows that the initial ability to master the concept of students in terms of understanding is very low. Overall, the initial ability to master the concept of students is included in the less category. After six sessions of treatment by applying learning using a critical multiliteracy model mastery of explanatory text concepts students experienced a significant increase. The results of the post-mastery mastery of explanatory text concepts can be seen in the following figure.

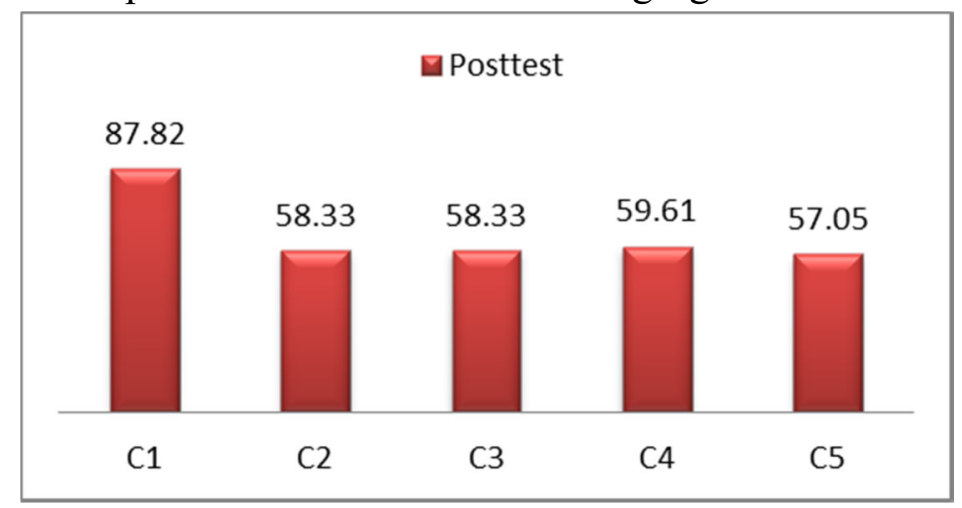

Figure 2. Posttest Results of The Mastery of Concepts 
Based on figure 2 it is known that the ability to master the concept of students after being given learning using the critical multiliteracy model has increased. The indicator remembering $(\mathrm{C} 1)$ gets the highest average score compared to other indicators. Differences in the average score between indicators remember with other indicators very far. While the average score obtained on the indicators of understanding, applying, analyzing, and evaluating is not significantly different. Based on these data, it has been found interesting that through the critical multiliteracy learning model, the recall indicator (C1) has increased significantly. Overall, the mastery ability of students' concepts after being given learning uses a critical multiliteracy model included in the sufficient category. This can be seen from the average score obtained by students of 64.20 .

Based on the explanation above, in general the ability to master the concept of students has increased significantly. To find out the improvement of students' mastery of conceptual skills can be seen in the following figure.

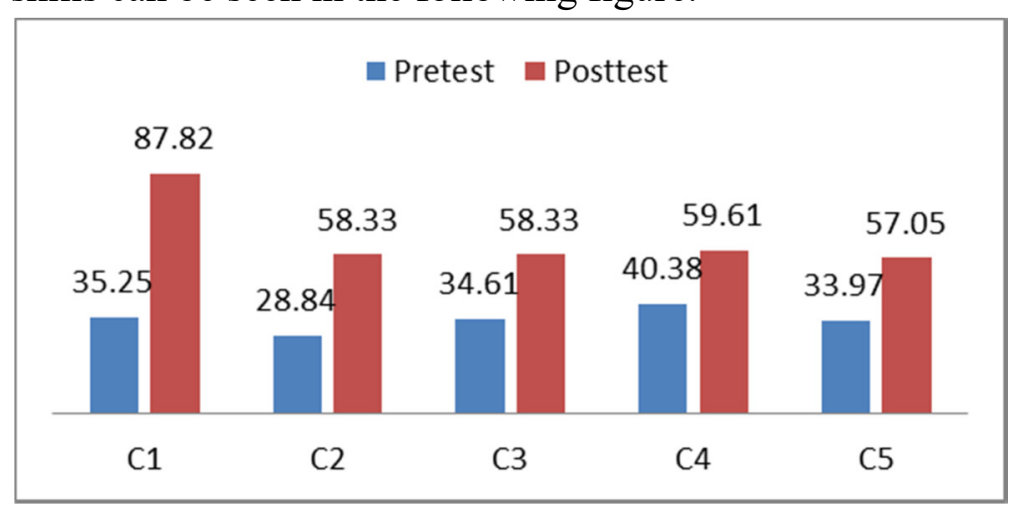

Figure 3. Results of Pretest and Posttest The Mastery of Concepts

Based on Figure 3, it shows that the mastery ability of the explanatory text concept of students has increased in each indicator. The most significant increase among other concept mastery indicators is the recall indicator (C1). The average score obtained by the $\mathrm{C} 1$ indicator is included in the excellent category. While the increase in the understanding indicator (C2), application (C3), analyzing (C4), and evaluating (C5) is not significantly different, so the average score of the four indicators is included in the sufficient category. From this explanation, there are interesting findings that through the application of critical multiliteracy models, $\mathrm{C} 1$ indicators can be improved significantly, but in the indicators of mastery of other explanatory text concepts, the increase that occurs is still unsatisfactory.

In connection with the explanation above, to see the increase in mastery of concepts more clearly, the researcher presents a different test table, two mean pre-test and posttest, namely as follows.

Table 1. Different Average Test of Pretest and Posttest for Student Assignment Concept

\begin{tabular}{ccccccc}
\hline Group & $\mathrm{N}$ & Mean & $\begin{array}{c}\text { Std. } \\
\text { Deviation }\end{array}$ & $\begin{array}{c}\text { Normality } \\
\text { test }\end{array}$ & $\begin{array}{c}\text { Mann- } \\
\text { Homogenity test }\end{array}$ Whitney test \\
\hline Pretest & 39 & 34.74 & 8.955 & 0.03 & - & 0.00 \\
\hline Posttest & 39 & 64.23 & 15.792 & 0.78 & & \\
\hline
\end{tabular}


Based on Table 1, it shows that the mastery ability of the explanatory text concept has increased significantly. This can be seen from the results of pre-test at 34.74 and post-test at 64.23. Then based on the results of the Mann-Whitney test it is known that the significance value is 0.00 , which means $<0.05$. Thus, there is a significant difference in mastery of the explanatory text concept of students between before and after being given learning using a critical multiliteracy model.

\subsection{Discussion}

Based on the findings, it shows that the mastery ability of the explanatory text concept of students has increased in each indicator. The most significant increase among other concept mastery indicators is the recall indicator $(\mathrm{C} 1)$. The average score obtained by the $\mathrm{C} 1$ indicator is included in the excellent category. While the increase in the understanding indicator (C2), applying (C3), analyzing (C4), and evaluating (C5) is not significantly different so that the average score of the four indicators is included in the sufficient category. From this explanation, there is an interesting finding that through the application of critical multiliteracy models it can significantly improve the recall indicator $(\mathrm{C} 1)$ but in the other indicators of mastery of the explanatory text concept the improvement that occurs is still unsatisfactory. Viewed as a whole, the mastery ability of the explanatory text concept of students has increased significantly and is included in the sufficient category. This can be seen from the results of pre-test at 34.74 and post-test at 64.23 . Then based on the results of the Mann-Whitney test it is known that the significance value is $0.00<0.05$, meaning that there is a significant difference in mastery of the explanatory text concept of students between before and after being given learning using a critical multiliteracy model.

The Mastery of the explanatory text concept of students has increased significantly after getting learning using critical multiliteracy models. This is because the critical multiliteracy model can encourage students to gain a deeper understanding of the concept of explanatory text through scientific thinking activities. The cognitive component has a fairly central role and has a significant influence in improving the mastery of students' concepts of learning [24]. In addition, critical multiliteracy models have a positive impact on students through learning steps that require students to think critically. The impact of critical thinking activities enriched with multiliteracy will strengthen students' knowledge, so that students gain a high understanding [25,26]. Not only that, the critical multiliteracy model also guides students to gain a good understanding of explanatory texts through modeling which students are then tasked with analyzing the text and followed by brainstorming. Modeling and analyzing explanatory texts is important so that students get a good understanding of the structure of explanatory texts, the characteristics of the explanatory text and explanatory text language rules.

\section{Conclusion}

Based on the results of the study, mastery of the explanatory text concept of students experienced a significant increase after being given learning using critical multiliteracy 
models. This means that the stages of the critical multiliteracy learning model are effective in increasing mastery of the concept of explanatory texts. The critical multiliteracy learning model has implications for the learning process, which can encourage students to be more active in the learning process, encourage students to gain high understanding, develop students' critical thinking skills, and improve student literacy.

\section{References}

[1] Republik Indonesia, Peraturan Mentri Pendidikan dan Kebudayaan, Nomor 24, 2016, tentang Kompetensi Inti dan Kompetensi Dasar Pelajaran pada Kurikulum 2013 pada Pendidikan Dasar dan Pendidikan Menengah.

[2] Kemendikbud. (2014). Buku Guru Bahasa Indonesia Wahana Pengetahuan Jakarta: Kemendikbud.

[3] Priyatni, E.T. (2014). Desain Pembelajaran Bahasa Indonesia dalam Kurikulum 2013. Jakarta: Bumi Aksara.

[4] Mahsun, (2014). Teks dalam Pembelajaran Bahasa Indonesia. Jakarta: Rajawali Pers.

[5] Anderson, M., \& Anderson, K. 1997a. Text Types in English 1. Melbourne: Macmillan Education Australia.

[6] Gerot, L. \& Wignell. (1995). Making Sense of Functional Grammar. Australia: Gerd Stabler.

[7] Derewianka, B. (1990). Exploring How Text Work. Newtown: PETA.

[8] Emilia, E. (2012). Pendekatan Genre-Based dalam Pengajaran Bahasa Inggris: Petunjuk untuk Guru. Bandung: Riqi Press.

[9] Knapp, P \& Watkins. (2005). Genre, Text, Grammar Technologies for Teaching and Assessing Writing. Sydney: University of New South Wales.

[10] Ting, S., Campbell, Y. M., Law, L., \& Poh, H. (2013). Explanations without a purpose ? Genre-based instruction and academic writing, 7(1), 26-39.

[11] Abidin, Y. (2015). Pembelajaran Multiliterasi Sebuah Jawaban atas Tantangan Pendidikan Abad Ke-21 dalam Konteks Keindonesiaan. Bandung: Refika Aditama.

[12] Freire, P. (2005). Education for Critical Consciousness. London: Continuum.

[13] Altas, B. (2014). A Case Study of Multimodal Presentation of Selected Stage Play Literature in a Multimedia Environment. Procedia - Social and Behavioral Sciences, 116, 1726-1734. https://doi.org/10.1016/j.sbspro.2014.01.463.

[14] Hesterman, S. (2011). A contested space: The dialogic intersection of ICT, multiliteracies, and early childhood. Contemporary Issues in Early Childhood, 12(4), 349-361. https://doi.org/10.2304/ciec.2011.12.4.349.

[15] Navehebrahim, M. (2011). Multiliteracies Approach to empower learning and teaching engagement. Procedia - Social and Behavioral Sciences, 29, 863-868. https://doi.org/10.1016/j.sbspro.2011.11.315.

[16] Giampapa, F. (2010). Multiliteracies, Pedagogy and Identities: Teacher and Student Voices rom a Toronto Elmentary School. Canadian Journal Of Education. 33,2 (2010). 407-431.

[17] Alexander, K. P., DePalma, M. J., \& Ringer, J. M. (2016). Adaptive Remediation and the Facilitation of Transfer in Multiliteracy Center Contexts. Computers and Composition, 41, 32-45. https://doi.org/10.1016/j.compcom.2016.04.005.

[18] Silvers, P., Shorey, M., \& Crafton, L. (2010). Critical literacy in a primary 
multiliteracies classroom: The hurricane group. Journal of Early Childhood Literacy, 10(4), 379-409. https://doi.org/10.1177/1468798410382354.

[19] Setiawan, D. (2019). Perbandingan Model Pembelajaran Multiliterasi Kritis dengan RADEC dalam Kemampuan Menulis dan Penguasaan Konsep Teks Eksplanasi Siswa Sekolah Dasar. (Tesis, Universitas Pendidikan Indonesia, 2019).

[20] Susilo, S. \& Ramdiati, T. (2019). Penerapan Model Multiliterasi Untuk Meningkatkan Keterampilan Menulis Karangan Persuasi Pada Mata Pelajaran Bahasa Indonesia Di Sekolah Dasar. Jurnal Cakrawala Pendas, 5 (1), pp. 2431.

[21] Dafit, F. (2017). Keefektifan Kemampuan Menulis Kreatif Siswa SD Dengan Model Pembelajaran Multiliterasi. Gerakan Aktif Menulis, 5, Hlm. 49-57.

[22] Nurhalimah, S. (2016). Perbandingan Efektivitas Model Multiliterasi Kritis dan Model Menulis Otentik Terhadap Kemampuan Menulis Teks Persuasi Siswa Sekolah Dasar. (Skripsi, Universitas Pendidikan Indonesia, 2016).

[23] Iskandar, C. C., Abidin, Y., \& Yunansah, H. (2016). Penggunaan Model Multiliterasi Kritis Untuk Meningkatkan Kemampuan Siswa Dalam Menulis Karangan Argumentasi. Jurnal PGSD Kampus Cibiru, 4(3).

[24] Decker, S. L., Roberts, A. M., Roberts, K. L., \& Stafford, A. L. (2016). Cognitive components of developmental writing skill, 53(6). https://doi.org/10.1002/pits.

[25] Allison, E., \& Goldston, M, J. (2018). Modern Scientific Literacy : A Case Study of Multiliteracies and Scientific Practices in a Fifth Grade Classroom, 27, 270283. https://doi.org/10.1007/s10956-017-9723-z.

[26] Iyer, R., \& Luke, C. (2010). Multimodal, Multiliteracies: Text and Literacies for the $21^{\text {st }}$ Century. Dalam Pullen \& Cole (Eds.). Multiliteracies and Technology Enhanced Education: Social Practice and the Global Classroom. New York: Information Science Reference (an imprint of IGI Global). 